NBER WORKING PAPER SERIES

\title{
GUNBOATS, REPUTATION, AND SOVEREIGN REPAYMENT: LESSONS FROM THE SOUTHERN CONFEDERACY
}

\author{
Marc D. Weidenmier \\ Working Paper 10960 \\ http://www.nber.org/papers/w10960 \\ NATIONAL BUREAU OF ECONOMIC RESEARCH \\ 1050 Massachusetts Avenue \\ Cambridge, MA 02138 \\ December 2004
}

This paper is forthcoming in the Journal of International Economics. The author thanks Howard Bodenhorn, Richard Burdekin, Jonathan Eaton, William English, Niall Ferguson, Greg Hess, Hugh Rockoff, Tom Willett, seminar participants at the March 2003 Sovereign Debt Conference held at the Social Science History Institute at Stanford, and an anonymous referee for comments. All remaining errors are the authors. The views expressed herein are those of the author(s) and do not necessarily reflect the views of the National Bureau of Economic Research.

(C) 2004 by Marc D. Weidenmier. All rights reserved. Short sections of text, not to exceed two paragraphs, may be quoted without explicit permission provided that full credit, including () notice, is given to the source. 
Gunboats, Reputation, and Sovereign Repayment: Lessons from the Southern Confederacy

Marc D. Weidenmier

NBER Working Paper No. 10960

December 2004

JEL No. F34, N2

\begin{abstract}
Many states that formed the Southern Confederacy defaulted on sovereign debt sold in international capital markets during the 1840s. The Confederacy also elected President Jefferson Davis, who openly advocated the repudiation of U.S. states' debts while a member of Congress. Despite its poor credit record, the Confederate government managed to float cotton bonds in England that constituted under two percent of its expenditures. The bonds were largely issued to settle overdue debts with gun contractors who had cut off trade credit. The South serviced the bonds as late as March 1865, a time of domestic hyperinflation and weeks before the fall of Richmond. Although the Confederate experience shows that trade sanctions can promote debt repayment, the gunboat model can only account for a small amount of lending. A reputation or another type of sanction would be necessary to support higher levels of lending in international capital markets.

Marc D. Weidenmier

Department of Economics

Claremont McKenna College

Claremont, CA 91711

and NBER

mweidenmeier@mckenna.edu
\end{abstract}




\section{Introduction}

The economics literature offers two explanations for sovereign debt repayment. One line of reasoning is that sovereign debtors repay for reasons of reputation (Eaton and Gersovitz 1981; Ozler, 1993; and Kletzer and Wright, 2000). Repayment safeguards the sovereign's reputation, granting it continued access to international capital markets in the future. The gunboat model, on the other hand, predicts that foreign creditors must be able to impose formal or informal sanctions such as a trade embargo or restrictions on trade credit to induce repayment. (Bulow and Rogoff, 1989a,b; Rogoff, 1999; Cole and Kehoe, 1997). ${ }^{1}$ Reputation is not a sufficient condition for repayment.

The Confederate experience during the American Civil War provides an experiment to examine the role of gunboats/sanctions and reputation in promoting sovereign repayment by a country with a very poor capital market reputation. Many Confederate states had a history of default in international capital markets. Arkansas, Florida, Louisiana, and Mississippi, for example, at least partially defaulted on bonds issued in London during the 1830s and 1840s. Jefferson Davis, future President of the Confederacy, openly supported repudiation of these debts while a member of the U.S. Senate from Mississippi in the 1840s (McGrane, 1935). The Confederate government also defaulted on all domestic debt obligations. The South sent a clear signal to foreign investors that they should stay away from rebel war bonds.

Despite a weak standing in international capital markets, the Confederacy managed to float two debt issues in Europe that amounted to less than two percent of Confederate war expenditures. Sold primarily in England, the cotton bonds were denominated in sterling, paid seven percent interest per year in sterling, and could be converted into cotton on demand. The

\footnotetext{
${ }^{1}$ For a literature survey of sovereign debt, see Eaton and Fernandez (1995) and Obstfeld and Rogoff (1996).
} 
Confederacy largely issued the 33 million-pound obligation in March 1863 to settle debts owed to the largest suppliers of rebel guns and military stores during the war. ${ }^{2}$ The Confederacy had fallen into arrears on its military contracts and British creditors cut off trade credit in November 1862 and reduced supply shipments. The threat of a gun embargo induced the fledgling nation to service the cotton bonds as late as March 1865, a time of domestic hyperinflation and just one month before the fall of Richmond and Lee's surrender at Appomattox. Elsewhere, the Confederacy raised only 22,500 pounds by floating eight percent coupon bonds in Amsterdam. The Confederacy never serviced its Dutch bonds. Foreign investors may have been wary of purchasing rebel war bonds because the South had a very poor capital market reputation, did not purchase many military goods in the Netherlands, and did not have assets in the Netherlands that could be seized to promote debt repayment.

Cotton bonds traded at a large premium relative to the Dutch bonds as well as all other Confederate debt obligations. Even in January 1865, when Richmond was on the verge of collapse and nearly surrounded by Union forces, cotton bonds traded for over 50 pounds sterling (half of par), while rebel money traded for two cents on the gold dollar. The Confederate experience is consistent with direct sanctions --trade or trade credit sanctions-- promoting debt repayment, but nevertheless supporting only a small amount of lending. A reputation (or another

\footnotetext{
${ }^{2}$ Grossman and Han (1996, p. 214) argue that the South did not need to borrow from international capital markets to smooth consumption at the beginning of the war: "The South had a large amount of mobilizable resources relative to their expected post-war endowment." They calibrate a theoretical model of moral hazard that indicates foreign markets charged the Confederacy a sufficiently high interest rate such that the South did not undertake additional foreign borrowing prior to defeats at Gettysburg and Vicksburg. One implication of their model is that the Confederacy was seen as a bad borrower because it could not credibly commit to spending enough to win the war.
} 
type of) sanction would be needed to support a higher level of lending in international capital markets than that implied by the gunboat model alone.

The paper begins with a brief literature review of empirical studies on debt repayment. This is followed by a discussion of the origins and history of the Confederacy's poor capital market reputation. Next, the terms of the South's two foreign debt issues are examined. Then the paper explores the implications of the Confederate experience for theories of sovereign repayment.

\section{Literature Review}

Many empirical studies of sovereign repayment have compared bond returns between defaulting and non-defaulting sovereigns over different historical periods. Eichengreen and Portes (1989), for example, examine bond returns for 125 London overseas issues as well as a sample of 250 U.S. foreign issues floated during the 1920s. They find that the "average" default reduced the internal rate of return 4.3 percent for dollar loans and approximately 2 percent for sterling loans. Alternatively, Lindert and Morton (1989) compare rates of returns on sovereign bonds for countries that defaulted and repaid their international debts between 1850 and 1970 . They find little evidence that defaulting countries were punished by creditors or denied future access to international capital markets. Tomz (2003) examines the history of sovereign default and lending over the past 300 years and finds that countries generally repaid their debts to maintain a good reputation in international capital markets.

In an important study, English (1996) examined U.S. states' defaults on bonds issued in London during the 1830s and 1840s. English notes that most states repaid their debts in full despite the lack of sanctions. States that repaid borrowed more in the years leading up to the Civil War. Repudiating states, on the other hand, generally found it difficult to secure finance 
from international capital markets. English concludes that U.S. states repaid their debts for reasons of reputation to maintain access to international capital markets.

More recent research has reexamined the gunboat model with a focus on informal, rather than formal or government-sponsored sanctions. Rogoff (1999, p. 31; also quoted in Rose, 2002, p. 8) suggests "The strongest weapon of disgruntled creditors, perhaps, is the ability to interfere with short-term credits that are the lifeblood of international trade." Market agents of a creditor nation may reduce trade credit and official agencies (i.e., U.S. Import-Export Bank) might offer higher insurance rates to punish a defaulting sovereign or to discourage future default. Rose's (2002) empirical analysis indicates that default leads to an 8 percent decline in international trade that persists for 15 years.

One problem with testing the gunboat model of repayment is that it is hard to identify the effect of formal or informal sanctions from macroeconomic fundamentals in gravity models and panel studies because a sovereign in default is often faced by a monetary or fiscal crisis. Disentangling these factors is what makes a historical case study, such as the Confederate States' experience, informative and useful. Empirical and historical evidence can be employed to determine whether formal or informal sanctions exist. If they do, to what extent do they promote repayment?

\section{A Country with a Very Poor Capital Market Reputation}

The Southern Confederacy's poor capital market reputation can be traced to the U.S. states' defaults of the 1840 s as well as being a new country at war and without formal diplomatic recognition by the major powers. Several Southern states, including Arkansas, Florida, Mississippi, and Louisiana, issued debt on the New York, Philadelphia, and London exchanges

during the 1830 s to raise capital to establish banks. The Panic of 1837 and the ensuing depression forced many banks to close and/or suspend interest payments in the early 1840s. 
Arkansas and Louisiana renegotiated and repaid most of their debts while Florida and Mississippi completely repudiated their obligations (English, 1996).

Mississippi's experience on the London exchange is especially noteworthy as foreigners held a large percentage of the bonds and Jefferson Davis was a U.S. Senator from the state at the time of default. Mississippi floated \$2 million dollars of state bonds in the early 1830 s to establish the Planters' Bank. A few years later, the state authorized \$5 million in bonds for the Union bank. The banks suspended interest payments in 1841 following the 1837 panic and economic downturn (McGrane, 1935). The state officially repudiated the Union bank bonds in 1842 and voted by plebiscite to default on the Planter's bank bonds in 1852 (English, 1996).

Mississippi Senator Jefferson Davis, future President of the Southern Confederacy, championed repudiation of state debts throughout this period. Davis even exchanged a series of letters with The Times defending Mississippi's international default. Davis "ridiculed the 'crocodile tears' which had been shed over the 'ruined creditors' and stated that Mississippi was not afraid of the verdict of the civilized world" (quoted in McGrane, 1935, p. 206).

Civil War capital markets were well informed of Jefferson Davis' views on sovereign default. United States officials published pamphlets in Europe detailing the Confederate President's support of states' defaults (Walker, 1864). The United States government obviously did not want foreign investors to forget about Davis' position on debt repudiation. Otherwise, foreign investors would be more inclined to purchase securities issued by the Confederacy in Europe. Robert Walker, a lawyer for the United States government in London reprinted an editorial in 1863 that appeared in The Times shortly after Mississippi defaulted on its bonds. ${ }^{3}$

\footnotetext{
${ }^{3}$ There is some debate about Walker's success in thwarting European financial houses from loaning to the Confederacy. A letter to the Editor of The Times dismissed claims that Jeff Davis' support of state defaults in Mississippi and Arkansas tarnished Confederate war debt. The letter noted that "Virginia, Georgia, and other honorable states were also part of the Confederacy," and
} 
"Let it circulate throughout Europe that a member of the United States Senate in 1849 [Jefferson Davis] has openly proclaimed, that at a recent period the Governor and legislative assemblies of his own State deliberately issued fraudulent bonds for five millions of dollars to 'sustain the credit of a rickety bank';..." (Walker, 1864, p. 392).

Walker's duties were not confined to publishing articles about Davis' position on sovereign default. He also traveled to leading investment houses in Europe to dissuade them from underwriting war debt on behalf of the Confederate government (Walker, 1863).

Domestic economic policy also contributed to the Confederacy's poor capital market reputation. The Confederacy was established on the basis of a weak central government that refused to pass tax legislation as well as collect levies that could be used to fund the war effort. Taxes accounted for only 8 percent of Confederate revenues during the war (Ball, 1992). The aversion to taxation is perhaps best described by Governor Moore of Alabama in the following statement:

"The collection of this tax, by the state would be an onerous and unpleasant duty as it imposes upon the state the necessity of enforcing the laws of the Confederate government against her own citizens" (quoted in Lerner, 1956, p. 165).

The Southern Confederacy also tried to raise war finance through domestic capital markets. The government floated two major loans during the first two years of the war, the $\$ 15$ million loan of 1861 and the $\$ 100$ million loan of 1862 . The Confederacy originally pledged to service the issues in specie but ultimately reneged, making interest payments in depreciated government Treasury notes. Subsequent bond issues proved less fruitful as Confederate investors sought to unload their money balances by purchasing commodities rather than government obligations. The Confederacy resorted to funding acts that artificially increased bond demand by

could pay off Confederate debts in the event of Southern defeat (The Times, March 19, 1863). However, the author of this letter was allegedly James Spence, a well-known Southern sympathizer (New York Times, December 9, 1865). 
compelling citizens to exchange money for bonds (Burdekin and Weidenmier, 2003). Ball (1991) estimated that debt issue accounted for approximately 33 percent of Confederate revenues during the war.

The inability to levy taxes and float bonds forced the Confederate government to rely on the printing press as its principal means of war finance. Between January 1861 and February 1864, the Confederate money supply increased 1,200 percent, rising from 100 million to more than 3,500 million (Lerner, 1955, 1956). Commodity prices, as measured by the Lerner Price Index, rose from an index value of 100 in early 1861 to 5,300 by March 1865 . Inflation averaged more than 10 percent per month during the war. Money financing accounted for approximately 59 percent of Confederate revenues (Schwab, 1901; Todd, 1954; Ball, 1991). The Confederacy's dependence on the inflation tax further diminished its poor capital market reputation.

\section{The Confederacy in International Capital Markets}

During the first two years of the war, the Confederacy did not attempt to float debt in international capital markets. The South believed that cotton was "King" and that a self-imposed cotton embargo would draw England and France into the war. They thought that European powers, especially England, were dependent on Confederate cotton to operate their textile mills. Although the Confederacy enjoyed considerable power in the world cotton market, many British textile mills were overstocked with Southern cotton early in the war because of a bumper crop in 1860 (Irwin, 2001). Southern planters shipped large quantities of cotton to England shortly after South Carolina seceded from the Union in the fall of 1860. Moreover, planters were unwilling to pass legislation that would curtail cotton production or grant the Confederate government power to confiscate the staple (Lebergott, 1983a). "King Cotton Diplomacy" not only failed to incite foreign intervention, but the Confederate government also lost an opportunity to purchase 
military supplies in Europe with cotton during the early stages of the war (Owsley, 1985; Ball, 1991).

By the end of 1862, Confederate revenues from money, debt, and taxes began to fall with rising inflation. A European loan could raise specie to buy guns and ships abroad as well as replenish Confederate gold reserves and bills of exchange depleted by the purchase of arms in England. Raising funds in Europe was a difficult prospect for the Confederacy, however, as their poor capital market reputation and unclear military prospects made it difficult to find financiers that would underwrite a foreign loan. Leading investment houses, such as the Rothschilds and Barings, refused to market war debt for a pro-slavery government with such a poor capital market reputation (Ferguson, 1999; Sexton, 2001).

The South discussed the possibility of floating a foreign loan with several second-tier firms during the latter part of 1862 . The Confederacy agreed in October to issue a 20 -year, £3 million-pound bond obligation with Emile Erlanger and Company, a French investment house. The sterling raised from the float could buy thousands of guns for the South, as a battle rifle cost about $£ 3.5$ pounds and gunships between $£ 60,000$ and $£ 90,000$ pounds, depending on their quality (Fenner, 1969). Erlanger initially offered to float a $£ 5$ million pound issue, but the Confederacy declined because it did not believe it could service such a large obligation.

The twenty-year security contained several provisions to minimize the risk for investors and Erlanger and Company. The sterling denominated issue paid 3.5 percent interest semiannually (in sterling) to minimize currency risk. The issue contained a sinking-fund provision that retired one-fortieth of the principal semi-annually through a lottery drawing. The underwriting firm agreed to sell the bonds at 90 percent face value (£90 pounds) and collect an 18 percent brokerage fee. As a result, the South received only $£ 2,160,000(72 \%)$ of the $£ 3$ millionpound issue (Economist, March 21, 1863). Investors paid into the subscription over a period of months according to the following schedule: 5 percent on application, 10 percent on allotment, 10 percent on May 1, 1863, 10 percent on June 1, 1863; 10 percent on July 1, 1863; 15 percent on 
August 1, 1863; 15 percent on September 1, 1863, less dividend of 3.5 percent; and 15 percent on October 1, 1863. The terms of the loan also called for Erlanger to administer the first two interest and principal payments that would be paid out of a portion of the initial bond subscriptions placed in a separate account under its control (Fenner, 1969). Erlanger received an additional 1 percent commission on all principal and interest payments made to investors. All remaining interest and principal payments would be made by the Confederate government. The small up front payment and the "guarantee" of debt service for a year were provisions obviously designed to reduce default risk for investors.

Bondholders also had the option to convert the war debt into cotton. Investors could buy New Orleans middling class cotton for 6 pence a pound from the Confederate government and return to England and sell the fiber at the market price. At the time of issue, cotton sold for approximately 24 pence a pound on the Liverpool exchange. To undertake the transaction, the bondholder first had to exchange the debt issue for cotton certificates with the Confederate representative in Europe. The investor then ran the blockade, took possession of the cotton in the South, and returned to Europe running the blockade a second time. ${ }^{4}$ To facilitate the exchange, the Confederate government agreed to transport the cotton to within ten miles of a navigable river or port (Economist, March 21, 1863). Foreign investors could not, however, legally sell their bonds to Confederates so that they would only have to run the blockade once. The Confederate government reprimanded and punished a Congressional representative who secretly tried to purchase shares in the war debt (Alexander and Beringer, 1972). The Confederacy serviced the

\footnotetext{
${ }^{4}$ Weidenmier (2000) provides historical evidence that a few cotton bondholders exercised the option, picked up the cotton in the Confederacy, and sold the staple at the high prices prevailing in Liverpool. Many more exchanged the war bonds for cotton warrants but did not run the blockade.
} 
cotton bonds for the duration of the war, making interest payments in sterling and exchanging the war debt for cotton in accordance with the terms of the contract.

In addition to the widely studied cotton bonds, the Confederate government also sold bonds in Amsterdam during the fall of 1863 and early 1864. The thirty-year security contained an 8 percent coupon that paid interest in sterling on January 10 and July 10 of each year (Bosch, 1948). The bonds initially sold at 50 percent of $\operatorname{par}(\mathrm{par}=£ 100$ pounds) in sizes of $£ 50,100,500$, and 1,000 pounds. The terms of the debt contract allowed the Confederacy to convert the 5-year security into 5-30 year bonds. The issue generated little enthusiasm among Dutch investors, raising only $£ 2,500$ pounds from the float (Gentry, 1970). ${ }^{5}$ Dutch investors were apparently wary of purchasing bonds from a rebel government that defaulted on its domestic bonds and recently suffered major defeats at Gettysburg and Vicksburg. Bosch (1948) notes that many Dutch investors were unwilling to buy bonds from a pro-slavery government with such a poor reputation. Foreign investors may also have been concerned that the war bonds did not contain provisions such as cotton collateral to promote repayment. Perhaps investors were aware of the fact that the Confederacy did not purchase many guns or have assets in the Netherlands that could be used to promote repayment.

The Confederate Treasury Secretary Christopher Memminger "forgot" about the Dutch bonds and did not mention the issue in his Treasury reports or memoirs. The South never serviced the war bonds and did not even attempt to make interest payments in depreciated Confederate Treasury notes. Rebel money was essentially worthless by early 1864 , trading for about 4 cents on the gold dollar in Richmond (Weidenmier, 2002).

\footnotetext{
${ }^{5}$ It is possible the Confederacy may have used the proceeds from the Dutch issue to service the cotton bonds. I have been unable to verify this hypothesis because the records of the Confederate Treasury do not mention the bonds sold in Amsterdam.
} 


\section{The Importance of Sanctions and Reputation}

The Confederacy's inability to sell coupon bonds in Amsterdam and the reluctance of the Barings and Rothschilds to underwrite debt for the rebel nation shows that the country's poor credit reputation played a role in limiting the amount of capital it could raise in international markets. Table 3 presents estimates of the net proceeds of the cotton loan derived from Gentry (1970). The Confederacy received approximately 1.519 million pounds sterling after accounting for the net loss from secret debt buybacks and resales, debts settled using repurchased cotton bonds, brokerage and commission costs paid to the French underwriting firm, and a loan secured using the cotton bonds as collateral. ${ }^{6}$ The net proceeds from the cotton loan fall to less than 1.081 million pounds sterling if the interest and principal payments, which were largely paid out of the funds raised from the float, are subtracted from the 1.519 million pound figure. The net resource transfer amounted to less than 2 percent of Confederate war expenditures using either estimate of the net proceeds.

Although the cotton loan was quite small, there is considerable evidence that the threat of trade and trade credit sanctions enforced the war loan and debt repayment. As shown in Table 1, the Confederacy secretly repurchased nearly half of the cotton bonds in April and May 1863 to buoy war debt prices after the bonds fell below their original offer price of $£ 90$ pounds. The Confederacy feared that subscribers would default on their remaining payments that would not be completed until October 1. The buyback program worked and subscribers made their scheduled payments. The Confederacy then resold many of the debt buybacks in the spring and summer of 1863 , leaving the Confederacy with $£ 1.63$ million pounds sterling. The South used some of the remaining repurchased bonds to settle outstanding debts. For example, the Confederacy owed the

\footnotetext{
${ }^{6}$ Ball (1991) and Owsley (1951) provide similar estimates of the net proceeds raised from the cotton bond issue.
} 
British firm Saul Isaac, Campbell and Company (hereafter SICC), £565,000 pounds. The company was one of the most important suppliers of guns and military stores such as canteens, cartridges, knapsacks, and uniforms for the Confederacy. The firm even extended trade credit to the rebel nation during the first two years of the war. By the fall of 1862, however, the Confederacy had fallen into arrears on their gun contracts. SICC restricted trade credit and asked for debt repayment. The move reduced gun shipments to the Confederacy. Fenner (1969) reports that the Confederacy had no trade credit in Europe from about November 1862 until March 1863, when Erlanger issued the cotton bonds. Table 1 shows that the Confederacy ultimately repaid its debt with SICC by giving the firm $£ 135,000$ pounds (market value) in cotton bonds and gold from the proceeds of the Erlanger loan in September 1863 (Fenner, 1969).

SICC proved invaluable to the Confederate war effort. They supplied the Confederacy with Enfield rifles, the standard battle arm of "Johnny Reb" (Wise, 1988), in addition to military stores. The military goods would then be loaded on ships that would run the Union blockade and dock at open Confederate ports on the Eastern Seaboard and the Gulf of Mexico. ${ }^{7}$ SICC apparently charged the rebels above market prices for military supplies to compensate for the possibility that the South might lose the war and default on their military contracts, leaving the British firm high and dry (Sexton, 2001). British manufacturers supplied nearly 60 percent of Confederate guns during the war (Owsley, 1951). It was crucial for the Confederacy to service

\footnotetext{
${ }^{7}$ One potential problem for the Confederacy was the Union blockade of Confederate ports. A blockade would make it pointless to sell bonds in Europe, as specie raised from a debt float could not easily be converted into guns. Lebergott (1983b) shows that the Union blockade was only partially effective. The capture rate for steam vessels was only 16.1 percent during the war. Fenner (1969) argues that the Confederacy's inability to borrow large sums of specie abroad, especially after defeats at Gettysburg and Vicksburg, as well as their poor regulation of blockade runners, explains why the Confederacy did not import more military goods from Europe.
} 
the cotton bonds so that SICC would not cut off shipments of guns and military stores that would cripple the rebel war effort.

Table 1 also shows that the Confederacy gave $£ 390,000$ pounds sterling in cotton bonds to Emile Erlanger and Company in September 1863 for underwriting the war bonds. ${ }^{8}$ Erlanger probably had less power than SICC to impose costly sanctions because the firm did not supply the rebels with guns or ships. Nevertheless, Erlanger and Company had the ability to disrupt debt service on the war bonds by interfering with the semi-annual payments of interests and principal during the first year when the firm administered the loan. Another factor that promoted debt service is that the Confederacy used repurchased cotton bonds as collateral for a loan. Table 1 shows that the Confederacy obtained a $£ 150,000$ pound loan from John K. Gilliat and Company in 1864 by putting up $£ 187,500$ pounds (market value) in cotton bonds as collateral (Fenner, 1969). Gilliat and Company negotiated shipbuilding contracts for the Confederacy. The South purchased military goods with the funds raised from the loan. The Gilliat loan represents the only time the Confederacy was able to secure a loan using repurchased cotton bonds.

Another reason the Confederacy may have serviced the cotton bonds is that important rebel shipbuilders purchased shares in the war debt. The New York Times reported December 9, 1865 that John Laird owned 200 cotton bonds. The Liverpool engineer designed and built the Laird Rams, two of the largest ironclads ever built during the Civil War (Dekay, 2002). The ships were more powerful than any vessel in the Union navy and could have inflicted substantial damage on the U.S. navy. The United States Foreign Service in London pressured the British

\footnotetext{
${ }^{8}$ The debt buybacks undertaken by Erlanger and the Confederacy required the two parties to renegotiate the French firm's underwriting commission. They both agreed that the Confederacy would settle the brokerage fees by giving Erlanger $£ 390,000$ pounds (market value) in cotton bonds.
} 
government to prevent these ships from leaving harbor. The United States argued that England would violate its neutrality if it permitted these ships to sail. England ultimately forced the Confederacy to sell the warships on the open market in the fall of 1863 . Laird, however, continued to build blockade-runners for the rebels that carried supplies to the Confederacy from Europe for the remainder of the war (Wise, 1988). ${ }^{9}$

The prospect of foreign intervention, especially by England, was another factor that may have promoted debt repayment. The Confederacy apparently believed that there might be political gain from floating war debt in Europe. Many high ranking Confederate officials thought that England might recognize the rebel nation or intervene in the conflict and negotiate an armistice. The possibility of recognition or intervention was unlikely, however, after the Confederate defeat at Antietam in September 1862 and the announcement of the Emancipation Proclamation that freed the slaves in January 1863 (Owsley, 1951). Many Britons were unwilling to back a rebel government that supported slavery. The British cabinet ceased discussions of recognizing the Confederacy as a sovereign country in the fall of 1862. Nevertheless, Judah Benjamin, the Confederate Secretary of War, believed that with a major military victory, the Confederacy might be able to sway British opinion in favor of the South. Benjamin alluded to the potential political gain from issuing the cotton bonds in the following correspondence with James Slidell, the Southern diplomat in Europe entrusted with negotiating the cotton loan. ${ }^{10}$

\footnotetext{
${ }^{9}$ Laird built several commerce raiders for the Confederacy, including the Alabama.

${ }^{10}$ The Confederacy's senior diplomats in Europe, James Mason and James Slidell, also discussed the political advantages likely to be derived from selling bonds collateralized by cotton in Europe. Consider Mason's comments on the Erlanger Loan: “These terms, although vastly better than the outline of the contract made in Paris were considered by us so onerous that we were unwilling to take the whole amount offered, and would have declined it altogether but for the political considerations indicated by Slidell” (Official Records, Vol. 3, p. 650).
} 
"Your intimation of political advantages likely to be derived from the [cotton] loan possessed great weight, though not as much as if you had felt at liberty to express yourself more definitely. We finally agreed, in view of that intimation, to make a sacrifice..." (Emphasis in the original) (quoted in Ball, 1992, p. 76).

Perhaps the Confederacy was aware that many important British politicians and businessmen planned to purchase shares in the cotton bonds. The New York Times also reported that William Gladstone, Chancellor of the Exchequer and future Prime Minister of England, along with several Members of British Parliament (MP), apparently purchased shares in cotton bonds. ${ }^{11}$ This group appears to have been responsible for several motions that called for recognizing the Confederacy as a sovereign nation in the British Parliament. William Lindsay, an MP and fervent supporter of the Confederacy, for example, apparently held more than $£ 15,000$ pounds --valued at par-- of Confederate cotton bonds. Shortly after the war bonds came to market in March 1863, he tried to secure recognition of the fledgling nation. Consider Lindsay's address to British Parliament, July 10, 1863:

"The question now before the House is one of far greater importance: it affects the peace and happiness of ten millions people: and as I hold the opinion, that if the word "recognition" was pronounced by England in concert with the Emperor of France and other European powers, that word would go forth as a harbinger of peace, and would restore peace with all the blessings that attend it..." (Hansard's Parliamentary Debates, July 10, 1863, p. 560).

${ }^{11}$ There is some controversy about whether Gladstone was a cotton bondholder. Morley (1903) and Sexton (2001) deny Bigelow's claim $(1988,1903)$ that the future Prime Minister owned Confederate cotton bonds. Morley was a close associate of Gladstone, however, and the weight of the evidence seems to support Bigelow's view. Not only did Gladstone meet with Confederate agents, but he also displayed a penchant for investing in risky debt throughout his political career. While he was Prime Minister, he dabbled in Egyptian bonds during the Suez crisis in 1882. 
Lindsay was not alone in his outspoken support for the South. Other prominent cotton bondholders, including Lord Robert Cecil, G. E. Peacocks, and William S. Gregory expressed views in favor of recognizing the Confederacy during Parliamentary debates. John Roebuck, another cotton bondholder, traveled to France to discuss with Napoleon III the possibilities of Anglo-French intervention in the American conflict. The meeting was not approved by the British government, prompting some members of Parliament to pressure pro-Southern MPs into withdrawing their motion of "Southern recognition" (Hansard's Parliamentary Debates, July 10, 1863, p. 661).

Confederate defeats at Gettysburg and Vicksburg in early July 1863 effectively ended the prospect of British intervention in the American Civil War. Hansard's Parliamentary Debates did not record a single discussion of "Southern recognition" after the two Confederate battle losses. Even pro-Southern British MPs were no longer willing to put their political capital at risk for a rebel government that was probably going to lose the war. In addition, the British government declined on several occasions in the summer of 1863 to meet with the Confederate representative James Mason, whose mission was to secure recognition from England. By August 1863, the Confederate government acknowledged diplomatic defeat and reassigned Mason to Europe where he spent much of the remainder of the war negotiating gun deals with French firms. Benjamin wrote to Mason that he should leave England because the British government "has determined to decline the overtures made through you for establishing, by treaty, friendly relations between the two governments, and entertains no intention of receiving you as the accredited Minister of this government near the British court" (quoted in Hubbard, 1998, p. 147). The failure of the Confederacy to achieve British support was also recognized by Henry Adams, a member of the United States foreign service in England, who closely monitored Confederate attempts to secure "recognition" or intervention by Her Majesty's government. Shortly after Northern victories at 
Gettysburg and Vicksburg, Adams wrote, "It is now conceded that all idea of [British] intervention is at an end" (quoted in McPherson, 1988, p. 664). ${ }^{12}$

\section{The March 1865 Interest Payment}

The Confederate military situation gradually deteriorated following defeats at Gettysburg and Vicksburg. Union armies pushed Confederate forces farther south in 1864 capturing Atlanta and Nashville. Northern armies controlled most of the Eastern Confederacy, except for small portions of North Carolina and Virginia, which were under attack by Union forces. Richmond, the Confederate capital, was almost completely surrounded by a Union army more than twice the size of the defending Southern forces. Only Texas and Northwest Louisiana in the Confederate Trans-Mississippi remained largely unoccupied by Union forces.

Mounting battle defeats placed enormous strain on the Confederate government as they relied on the printing press to extract resources from the economy. By early 1865, the South experienced hyperinflation as monthly commodity inflation rose above 50 percent. Money and bond demand fell as citizens and speculators sold Confederate denominated securities that would become worthless in the event of defeat. Confederate Treasury notes traded for less than two cents on the gold dollar and interest rates on government debt in Richmond and Amsterdam climbed to more than 150 percent in January 1865 (Burdekin and Weidenmier, 2003).

Despite the desperate military and financial situation, the Confederacy serviced the cotton bonds in September 1864 and March 1865 (Gentry, 1970). Figure 1 implies that financial markets understood that the cotton bonds represented the Confederacy's senior debt. The cotton bonds traded for about 50 pounds sterling (1/2 par) in January 1865, a large premium to rebel

\footnotetext{
${ }^{12}$ The Civil War historian James McPherson (1988, p. 664) refers to Southern defeats at Gettysburg and Vicksburg as the "coup de grace of Confederate hopes for recognition."
} 
money, expressed as the gold price of 100 Confederate Treasury notes, and Dutch bonds. ${ }^{13}$ The high price of the cotton bonds at this late stage of the war suggests that financial markets believed the South intended to service the war bonds as long as there was some hope for the "cause" (Pollard, 1994). Consistent with this belief, President Davis and General Lee vowed to fight on even after abandoning Richmond April $1^{\text {st }}$. General Lee attempted to join forces with General Johnson's army in North Carolina before being encircled at Appomattox. He surrendered to Northern forces April 12 and Johnson a week later. General Kirby-Smith, Commander of the Trans-Mississippi, held out much longer and continued to receive gun shipments from Europe through the ports of Matomoros (Mexico) and Galveston (Texas) before surrendering the last major Confederate army on May 26, 1865.

Table 2 shows the September 1864 and March 1865 interest and principal payments along with an estimated breakdown of the debt issue into bonds still owned by the Confederacy, bonds converted into cotton, and bonds held by the public. Private investors owned more than $£ 1.9$ million pounds of the initial $£ 3$ million pound issue. The Confederacy made interest and principal payments (for the sinking fund) in September 1864 and March 1865 totaling nearly $£ 234,500$. The Confederacy serviced the cotton bonds by using some of the remaining proceeds of the initial float and through the last-minute sale of ships built in Europe (Gentry, 1970). Given the South's poor capital market reputation and their willingness to liquidate assets to make interest and principal payments, there can only be one reason to explain why the Confederacy serviced the cotton bonds: gun sanctions. In 1862 when SICC reduced gun shipments, the

\footnotetext{
${ }^{13}$ Daily price data for the cotton bonds were collected from the Liverpool Daily Post. All available price data for the Dutch issue were collected from the Amsterdamsch Effectenblad. Confederate money price data are taken from Weidenmier (2002).
} 
Confederacy again feared that British firms would cut off trade credit and the supply of military goods, crippling the rebel armies that relied primarily on foreign manufacturers. ${ }^{14}$

\section{Conclusion}

Many states that formed the Southern Confederacy had a history of default in international capital markets. The election of Jefferson Davis as the Confederacy's President contributed to the new country's poor capital market reputation because the leader supported debt repudiation by U.S. states during the 1840s. Default on all domestic obligations further diminished the Confederacy's reputation, limiting its ability to borrow from international capital markets. Nevertheless, the South succeeded in floating cotton bonds in England that comprised less than two percent of Confederate war expenditures.

The threat of trade and trade credit sanctions by gun manufacturers promoted debt repayment by the Confederacy as late as March 1865 despite the onset of hyperinflation and Northern forces at the gates of the rebel capitol. The South had virtually no capital market reputation at this point of the war as rebel money was essentially worthless and interest rates on government bonds exceeded 150 percent. Although the Confederate experience shows that direct sanctions (trade and trade credit sanctions) can promote repayment, the gunboat model can only

\footnotetext{
${ }^{14}$ Another possible reason the Confederacy continued to service the cotton bonds is that the Northern siege of Richmond disrupted communications between the Rebel government and its agents in Europe. Confederate agents in England continued to service the war bonds because they had not been advised otherwise. Although the siege of Richmond and the tightening of the blockade certainly impaired communications, Confederate officials in Richmond and Europe continued to exchange diplomatic correspondence until the fall of Richmond April $1^{\text {st }} 1865$ (see Official Records, 1865).
} 
support a small amount of lending. A reputation (or another type of) sanction is necessary to support a higher level of lending and repayment in international capital markets. 


\section{References}

Alexander, T.B., Beringer, R.E., 1972. The Anatomy of the Confederate Congress. Vanderbilt University Press, Nashville.

Amsterdamsch Effectenblad, various issues, 1863--1865.

Ball, D.B., 1991. Financial Failure and Confederate Defeat. University of Illinois Press, Urbana.

Bigelow, J., 1888. France and the Confederate Navy: An International Episode. Harper and Brothers, New York.

Bigelow, J., 1905. Lest We Forget: Gladstone, Morley, and the Confederate Loan of 1863. De Vinne Press, London.

Bosch, K.D., 1948. De Nederlandse Beleggingen in de Verenigde Staten. Elsevier, Amsterdam.

Brown, W.O., Burdekin, R.C.K., 2000. Turning points in the U. S. Civil War: a British perspective. Journal of Economic History 60, 216--231.

Bulow, J., Rogoff, K.S., 1989a. Sovereign debt: Is to forgive to forget? American Economic Review 79, 43--50.

Bulow, J., Rogoff, K.S., 1989b. A constant recontracting model of sovereign debt. Journal of Political Economy 97, 155--178.

Burdekin, R.C.K., Weidenmier, M.D., 2001. Inflation is always and everywhere a monetary phenomenon: Richmond vs. Houston in 1864. American Economic Review 91, 1621--1630.

Burdekin, R.C.K., Weidenmier, M.D., 2003. Suppressing asset price inflation: the Confederate experience, 1861-1865. Economic Inquiry 41, 420--432.

Capers, H.D., 1893. The Life and Times of C. G. Memminger. Everett Waddey, Richmond.

Cole, H.L., Kehoe, P.J., 1997. Reviving reputation models of international debt. Federal Reserve Bank of Minneapolis Quarterly Review 21, 21--30.

Dekay, J.T., 2002. The Rebel Raiders: The Astonishing History of the Confederacy's Secret Navy. Ballantine Books, New York. 
Eaton, J., Fernandez, R., 1995. Sovereign debt, in: Grossman, G., Rogoff, K.S. (Eds.), Handbook of International Economics. Vol. 3. North-Holland, Amsterdam, pp. 2032-2077.

Eaton, J., Gersovitz, M., 1981. Debt with potential repudiation: theoretical and empirical analysis. Review of Economic Studies 48, 289--309.

Economist, various issues, 1863--1866.

Eichengreen, B. and Portes, R., 1989. After the deluge: default, negotiation, and readjustment during the interwar years, in: Eichengreen, B., Lindert, P.H. (Eds.), The International Debt Crisis in Historical Perspective. MIT Press, Cambridge, pp. 12--47.

English, W.B., 1996. Understanding the costs of sovereign default: American state debts in the 1840's. American Economic Review 86, 259--275.

Fenner, J.A., 1969. Confederate Finances Abroad. Unpublished Ph.d. Dissertation. Rice University.

Ferguson, N., 1999. The House of Rothschild. Penguin, New York.

Gentry, J.F., 1970. A Confederate success in Europe, the Erlanger Loan. Journal of Southern History 36, 157--188.

Grossman, H.I., Han, T., 1996. War debt, moral hazard, and the financing of the Confederacy. Journal of Money, Credit, and Banking 28, 200--215.

Hansard's Parliamentary Debates, 1863-1866.

Hubbard, C.M., 1998. The Burden of Confederate Diplomacy. University of Tennessee Press, Knoxville.

Irwin, D.A., 2003. The optimal tax on antebellum cotton exports. Journal of International Economics 60, 271--291.

Kletzer, K.M., Wright, B.D., 2000. Sovereign debt as intertemporal barter. American Economic Review 90, 621--639.

Lebergott, S., 1983a. Through the blockade: the profitability and extent of cotton smuggling, 1861-1865. Journal of Economic History 70, 867--888.

Lebergott, S., 1983b. Why the South lost: commercial purpose in the Confederacy, 1861-1865. Journal of American History 70, 58--74. 
Lerner, E.M., 1955. Money, prices, and wages in the Confederacy, 1861-65. Journal of Political Economy 62, 506--522.

Lerner, E.M., 1956. Inflation in the Confederacy, 1861-1865. In: Friedman, M. (Ed.), Studies in the Quantity Theory of Money. University of Chicago Press, Chicago, pp. 263--175.

Lester, R.I., 1972. Confederate Finance and Purchasing in Great Britain. University of Virginia Press, Charlottesville.

Lindert, P.H., Morton, P.J., 1989. How sovereign debt has worked. In: Sachs, J. D. (Ed.), Developing Country Debt and the World Economy. Chicago University Press, Chicago, pp. 225--235.

Liverpool Daily Post, various issues, 1863--1865.

McGrane, R.C., 1935. Foreign Bondholders and American State Debts. Macmillan and Company, New York.

McPherson, J.M., 1988. Battle Cry of Freedom. Oxford University Press, New York.

Morley, J., 1903. The Life of William Ewart Gladstone. MacMillan Company, London.

New York Times, various issues, 1865.

Obstfeld, M., Rogoff, K.S., 1996. Foundations of International Macroeconomics. MIT Press, Cambridge.

Official Records of the Union and Confederate Navies During the War of Rebellion 1922. Vol. 3. Serial II. United States Government, Washington.

Owsley, F.L., 1951. King Cotton Diplomacy: Foreign Relations of the Confederate States of America. Chicago University Press, Chicago.

Ozler, S., 1993. Have commercial banks ignored history? American Economic Review 83, 608--620.

Pollard, E.A., 1994. The Lost Cause. Gramercy Books, New York.

Rogoff, K.S., 1999. International institutions for reducing global instability. Journal of Economic Perspectives 13, 21--42. 
Rose, A.K., 2002. One reason countries pay their debts: renegotiation and international trade. NBER Working Paper No. 8853.

Sexton, J., 2001. Transatlantic financiers and the Civil War. American Nineteenth Century History 2, 29--46.

Schwab, J.C., 1901. The Confederate States of America. Charles Scribner's Sons, New York.

Todd, R.C., 1954. Confederate Finance. University of Georgia Press, Athens.

Tomz, M., 2003. Sovereign Debt and International Cooperation: Reputational Reasons for Lending and Repayment. Unpublished book manuscript, Stanford University.

Walker, R.J., 1864. American Slavery and Finances. William Ridgeway, London.

Weidenmier, M.D., 2000. The Market for Confederate Cotton Bonds. Explorations in Economic History 37, 76--97.

Weidenmier, M.D., 2002. Turning Points in the U.S. Civil War: Views from the Grayback Market. Southern Economic Journal 68, 875--890.

Wise, S.D., 1988. Lifeline of the Confederacy: Blockade Running During the Civil War. Columbia: University of South Carolina Press. 


\section{Table 1}

\section{Proceeds of the Cotton Loan (Pounds Sterling)}

Initial Amount received (90\% of $£ 3,000,000)$

Less: Debt Buybacks of 1,517,000@,90.96

(April $1^{\text {st }}-$ May $\left.1^{\text {st }}, 1863\right)$

Plus: Partial Resale of Repurchased Bonds

(April 30 - October $1^{\text {st }}, 1863$ )

Plus: Debt Settlement with Saul, Isaac, Campbell and Company 150,000@90

(May 31, 1863)

Receipts from transfer of bonds

Plus: interest received to September 30, 1864

(from Erlanger administering the accounts to this point)

Gilliat's Loan (May 1864)

Gross Receipts

Less: Erlanger's $13 \%$ profit commission

(Paid in Bonds, 443,000@ @8, May 31, 1863)

Erlanger's 1\% Commission (partially estimated)

Miscellaneous Expenses of issue

Expenses of agency

Net Proceeds

Less: Interest and Principal Payments

(September 1863 - March 1865)

Net Proceeds

(after subtracting Interest and Principal Payments)
$£ 2,700,000$

$(1,379,863)$

310,036

$1,455,137$

8,784

150,000

$2,313,957$

$(390,000)$

$(4,381)$

$(4,572)$

$(5,110)$

$£ 1,519,894$

$(438,180)$

$£ 1,081,714$

Source: Gentry (1970) 


\section{Table 2}

\section{Interest and Principal Payments (£) September 1864 and March $1865^{\mathrm{a}}$}

September 1864

March 1865 (estimated)

Total

$\begin{array}{cll}\text { Interest } & \text { Principal } & \text { Total } \\ £ 68.583 & 51,200 & 119,783 \\ 66,926 & 47,804 & 114,730 \\ & & \mathbf{2 3 4 , 5 1 5}\end{array}$

\section{Estimated Ownership Status of Cotton Bonds, March 1865}

Total Loan

Less: Bonds owned by Confederacy Bonds previously drawn (sinking-fund)

Bonds converted to cotton

Bonds owned by the public:
$£ 3,000,000$

609,000

102,629

376,200

$1,912,171$

Source: Gentry (1970, p. 166--167)

${ }^{a}$ Gentry used surviving Confederate records to estimate the September 1864 and March 1865 interest and principal payments. The debt service costs for September 1864 come directly from primary source documents. For the 1865 payment, Gentry estimated the outstanding number of cotton bonds held by investors by subtracting off the number of bonds converted into cotton warrants and owned by the Confederacy. The outstanding number of cotton bonds was derived from communications between Erlanger, Southern agents in Europe, and the Confederate government. In accordance with the contract terms of the loan, she then calculates the principal payment to be 2.5 percent of the face value of bonds held by investors, and the interest payment to be 3.5 percent of the face value of the outstanding bonds. 
Figure 1

Confederate Cotton Bond, Dutch Bond, and Money Prices March 1863 - April 1865

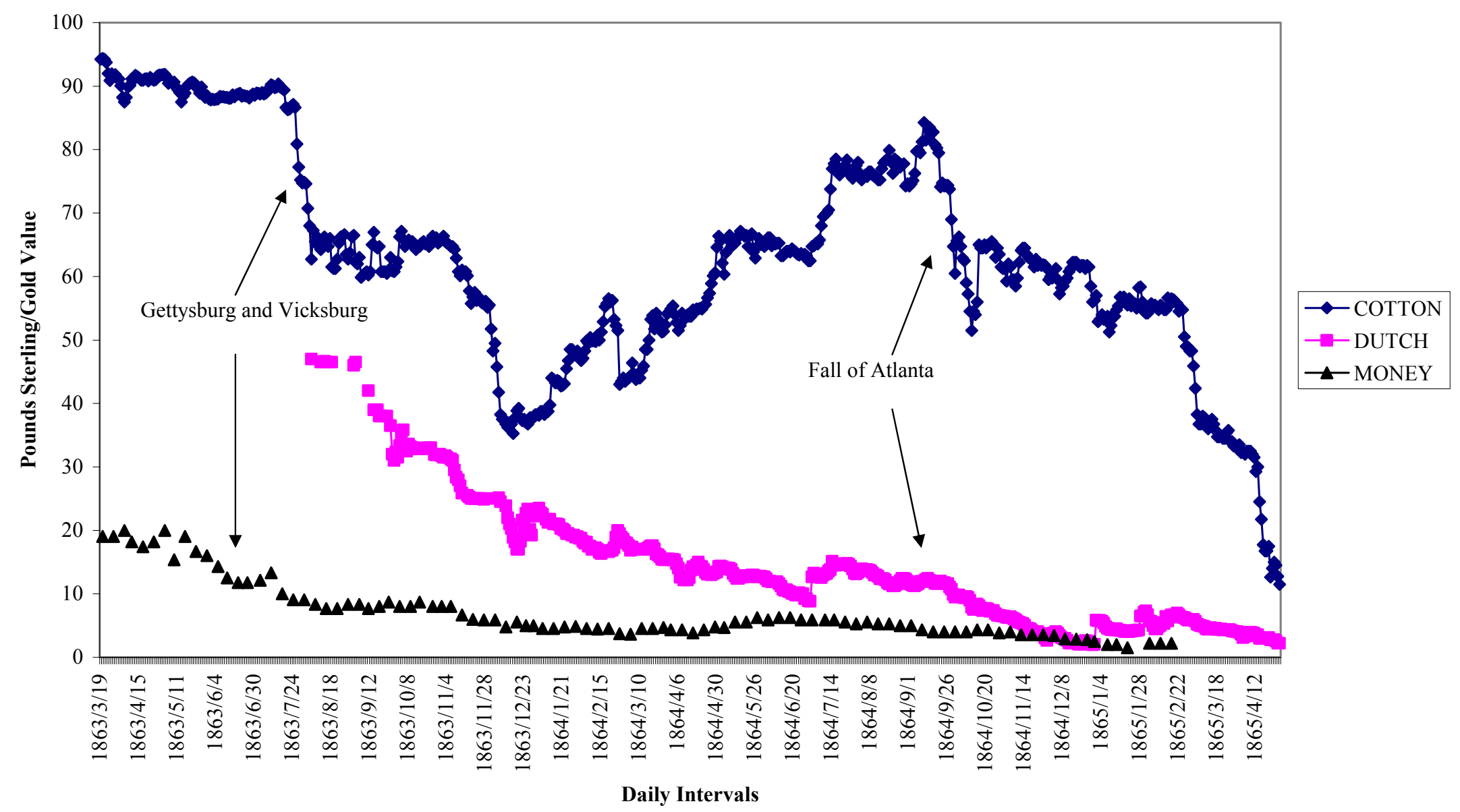

